\title{
Graphite Dendrites in Cast Iron and Their Fundamental Role in the Control of Morphology to Obtain Aero-Eutectic Graphite
}

\author{
Alicia N. Roviglione ${ }^{1, *}$, Alvaro Y. Tesio ${ }^{2}\left(\mathbb{D}\right.$, Fernando Fungo ${ }^{3}\left(\mathbb{D}\right.$ and Ricardo W. Gregorutti ${ }^{4}(\mathbb{D}$ \\ 1 Departamento de Ingeniería Mecánica, Facultad de Ingeniería, Universidad de Buenos Aires, \\ Av. Paseo Colón 850, C1063ACV Ciudad Autónoma de Buenos Aires, Argentina \\ 2 Centro de Investigación y Desarrollo en Materiales Avanzados y Almacenamiento de Energía de \\ Jujuy (CIDMEJu), Centro de Desarrollo Tecnológico General Manuel Savio, Y4612 Palpalá, Argentina; \\ atesio@cidmeju.unju.edu.ar \\ 3 Instituto de Investigaciones en Tecnologías Energéticas y Materiales Avanzados, (UNRC-CONICET) \\ Departamento de Química, Universidad Nacional de Río Cuarto, Agencia Postal 3, \\ X5804BYA Río Cuarto, Argentina; ffungo@exa.unrc.edu.ar \\ 4 LEMIT-Comisión de Investigaciones Científicas de la Provincia de Buenos Aires, Av. 52 e/121 y 122, \\ B1900AYB La Plata, Argentina; ricardo.gregorutti@cyt.cic.gba.gob.ar \\ * Correspondence: arovi@fi.uba.ar
}

check for

updates

Citation: Roviglione, A.N; Tesio, A.Y; Fungo, F.; Gregorutti, R.W Graphite Dendrites in Cast Iron and Their Fundamental Role in the Control of Morphology to Obtain Aero-Eutectic Graphite. Minerals 2021, 11, 109. https://doi.org/10.3390/min11020109

Received: 18 December 2020

Accepted: 19 January 2021

Published: 22 January 2021

Publisher's Note: MDPI stays neutral with regard to jurisdictional claims in published maps and institutional affiliations.

Copyright: (C) 2021 by the authors Licensee MDPI, Basel, Switzerland. This article is an open access article distributed under the terms and conditions of the Creative Commons Attribution (CC BY) license (https:// creativecommons.org/licenses/by/ $4.0 /)$.

\begin{abstract}
This work analyzes the growth of graphite in the eutectic system of gray cast iron, focusing on laminar type A and undercooled type D morphology, and a modified morphology, such as vermicular or compact graphite. The objective of the study is to find an optimal graphite structure, from which a new class of lightweight materials results that has been called aero-eutectic graphite (AEG). The method to obtain AEG consists of dissolving the gray iron ferrous matrix by means of a chemical attack. From experiences of unidirectional solidification, it has been found that laminar graphite grows in a non-faceted way, coupled to austenite, while in vermicular the growth is through foliated dendrites. This characteristic allows vermicular graphite to have a higher specific intrinsic surface area. According to the Brunauer-Emmett-Teller (BET) analysis, the surface of the vermicular was $106.27 \mathrm{~m}^{2} \mathrm{~g}^{-1}$, while those corresponding to type A and D were $83.390 \mathrm{~m}^{2} \mathrm{~g}^{-1}$ and $89.670 \mathrm{~m}^{2} \mathrm{~g}^{-1}$, respectively. AEG with graphite type $\mathrm{D}$ was used as a cathode in $\mathrm{Li}-\mathrm{O}_{2}$ batteries with satisfactory results, reaching more than 70 charge and discharge cycles, and 150 cycles at this time and still cycling, using $\mathrm{Ru}(\mathrm{bpy})_{3}\left(\mathrm{ClO}_{4}\right)_{2}$ as redox mediator.
\end{abstract}

Keywords: graphite growth; graphite foliated dendrite; porous graphite; hierarchical porous structure; $\mathrm{Li}_{-} \mathrm{O}_{2}$ battery cathode; ruthenium complex

\section{Introduction}

\subsection{About the Objective of This Work: Aero-Eutectic Graphite (AEG)}

In this work, a new material called aero-eutectic graphite (AEG) is presented, made with $100 \%$ crystalline pure eutectic graphite $(\mathrm{G})$ obtained from gray cast iron. It is a very light material, with a large surface area and different types and sizes of porosities suitable for assembling different simple and specific functions in an integrated process of greater complexity. For this reason, it belongs to the so-called hierarchically structured materials [1] Its versatility is enhanced, because it can be designed by the controlled solidification of cast iron. A subsequent dissolution of the metal matrix, by means of using a specially-designed technique that consists of sequential acid attack with different acids, allows preserving the structural integrity of the eutectic graphite to finally obtain various types of AEG (AEGs). These, in turn, can be subsequently adapted to achieve different objectives through specific functionalization. Some of AEG's possible applications may be catalyst support, electrodes, or diffuser plates for the production and/or storage of energy in batteries, fuel cells, and super capacitor, etc. Here we will refer its recent use as a cathode in $\mathrm{Li}-\mathrm{O}_{2}$ batteries [2] 


\subsection{Briefly, About the Basic Graphite Crystallography and Derived Properties}

$\mathrm{G}$ is an open crystal (pinacoid type, analogous to $\mathrm{CdI}_{2}$ and $\mathrm{MoS}_{2}$ ) that results from the stacking of at least three layers of $\mathrm{sp}^{2}$ atoms of $\mathrm{C}$ bonding by strong covalent unions in a regular hexagonal disposition called basal planes $\{00.2\}$. These planes in turn are joined between them with Van der Waals bonds, and their habit is closed with shapes $\{11.0\}$ and $\{10.0\}$ called prism planes. Depending on the type of layer stacking, generally indicated as $A B C A B C$ or $A B A B$ (where layer $A$ is identical to layers $B$ and $C$, but displaced between them by a $/ 3<11.0>$ ) two stable allotropic varieties of $G$ under normal pressuretemperature are formed: the $\mathrm{ABCABC}$ stack called hexagonal G (D6h4-PG3/mmc; unit cell constants: $\mathrm{a}=245.6 \mathrm{pm}, \mathrm{c}=670.8 \mathrm{pm}$ ) [3] and the ABAB stack (D3d5-R3m; unit cell constants: $a=256.6 \mathrm{pm}, \mathrm{c}=1006.2 \mathrm{pm}$ ) [3], slightly less stable, called rhombohedral G, which is obtained by mechanical deformation of hexagonal G .

Some other types of $\mathrm{G}$ were proposed from crystallographic considerations by Holcombe, and the characteristic spacing associated with its presence have been identified by $X$-ray diffraction in the following varieties: interdendritic laminar graphite Type D (LDG), compacted graphite (CG) and nodular graphite (NG) $[4,5]$. These varieties are the product of extensive stacking faults in the basal planes [6]. There are other stacking faults originated by the rotation of the basal planes in preferential angles to fit in a "coincidence networks" with lesser energies. All these faults increase the rigidity of the phase as the thickness of the sheet increases [7]. There are other phase defects that are relevant to explain shape change processes, such as the curving of a pinacoid shape [8] or emergence from the basal plane of a new crystallite with a different orientation. More details of the different types of twins, tilt boundaries, and dislocation arrangements are described in [9].

\subsection{About Some of Our Theoretical Guides}

G pinacoids would normally be similar to plates or flat leaves. Saratovkin [10] was the first to propose that one of the growth forms of open faceted crystals is through foliated dendrites, as may be seen in Figure 1.

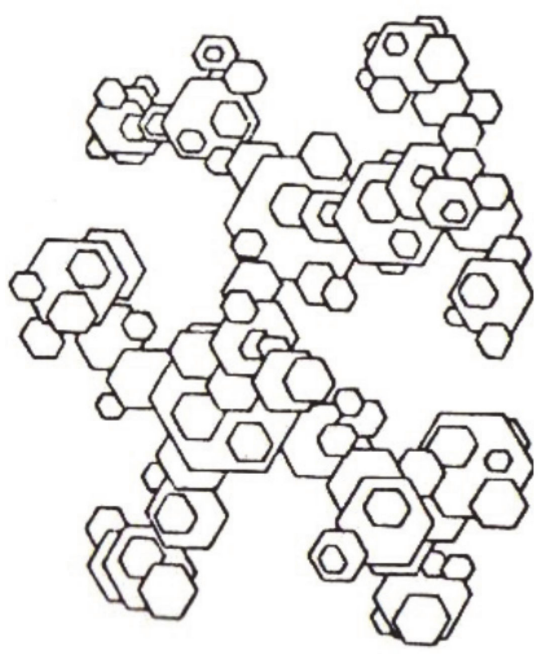

(a)

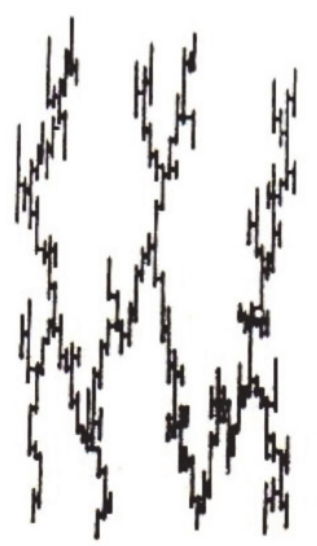

(b)

Figure 1. Scheme of the foliate dendrites proposed by Saratovkin [10]: (a) in plane; (b) in section.

This type of crystalline G was first mentioned, as far as we know, in 1991, in relation to the formation of kish $\mathrm{G}$ in cast iron, by Liu and Loper [11]. Almost simultaneously, Roviglione and Biloni $[12,13]$ reported that foliated graphite dendrites are the constituting elements of compact G (CG) and nodular G (NG). After that, in 2002, Roviglione and Hermida [14] published crucial results obtained by using a new technique that permits restricted solidification, in-situ addition of modifier alloys, and also subsequent interruption of solidification just in front of solid/liquid interface by an original freezing procedure. 
Finally, in 2004, the same authors formalized a theory that explains the reversible and continuous transition between the laminar and morphologically-modified G. Its explanation is based precisely in the change of type of growth of $\mathrm{G}$ from a non-faceted to a faceted one, adopting the form of foliated dendrites [15]. More recently, in 2016, Stefanescu et al. [16], in a very interesting work, mentioned that Saratovkin "used the foliated dendrite growth mechanism to explain iron entrapment between graphite layers during graphite growth in cast iron". Unfortunately, there are not cited works on this matter that may be very relevant to the object of the present study, as will be discussed latter. Certainly, there exist forms similar to leaves in the so-called gray cast iron, where flakes or lamellas of graphite are distributed in a network of interconnected sheets inside the ferrous matrix, known as lamellar graphite (LG). By modifying solidification parameters, different morphologies and distributions of LG are obtained, classified by ASTM A247 standard [17]. By means of increasing the undercooling, finer lamellar graphite can be obtained, producing a transition from laminar graphite type A (LAG) to type D (LDG) [18]. In the directional solidification study, it has been observed that $S$ and Te promote that transition, while Ti additions lead to very fine interdendritic G [19]. The greater fineness of graphite increases the interface graphite/matrix that, in turn, will render in a high specific surface area in AEG, which is a very relevant property for the new functionalities that are expected for it. Additionally, after different kinds of procedures, other external forms of $\mathrm{G}$ appear. They look similar to spheres and worms, better known as spheroidal and vermicular cast iron, or, alternatively, as NG or CG, respectively, as earlier was said. On the other hand, the role of the eutectic partner of $\mathrm{G}$, the eutectic austenite, has not been as well researched, or taken into account in the morphological modification (MM) of the eutectic itself. This is true when being compared to the amount of works that have been devoted to the influence of primary austenite on mechanical properties. For our purposes, the removal of the primary austenite lattice in AEG is very useful because, as a result of the growth mode in the FCC system, the dendritic branches grow in the $<100>$ directions, so after chemical dissolution, they leave a type of straight cylindrical pores of great length, fixed diameter, and branched at $90^{\circ}$. All this is optimal for the conduction of fluids through the porous structure. Perhaps, for this reason, it is quite appropriate the recent research made by Hernando et al. [20] in which, by cyclic remelting followed by a retention time, where solid and liquid coexist before solidification, an isothermal thickening process of the primary austenite dendrites network was achieved. Obviously, this provides a way to manipulate these pores in AEGs.

Eventually, there is a controversy over what is the "natural" way of growth for graphite, which does not have much sense, since, for each composition and growth conditions during the eutectic transformation, the system adopts the one which is less expensive in terms of energy and the more accessible in terms of kinetics which, at the same time, is more "natural" for the circumstances. The discussion about MM has been taking place for decades and it will probably continue. There still are many unanswered questions. However, the increasing access to cutting-edge technologies can most definitely help answer them. Naturally, excellent updated reviews may be consulted [21].

\section{Materials and Methods}

\subsection{AEG Manufacturing}

Gray cast iron with laminar LAG and LDG, and CG cast iron have been made to obtain AEGs with the desired structures. LGD iron was cast in $6 \mathrm{~mm}$ thick plates to achieve the necessary undercooling to obtain this graphite morphology, while LAG and CG irons in $12.7 \mathrm{~mm}$ " $Y$ " blocks. CG morphology was obtained by means of adding the necessary amount of FeSiMgCeCa alloy (8-10 Mg, 44-47 Si, 0.7-1.5 Ca, 1-1.2 Ce, balance Fe, in wt\%) to the liquid metal at $1450{ }^{\circ} \mathrm{C}$, by means of using the sandwich technique in ladle.

Square samples of $6 \mathrm{~mm}$ side were cut and mechanically thinned to $0.5 \mathrm{~mm}$ thickness, keeping the faces parallel and subsequently polished to \#1000 silicon carbide papers. After that, the matrix was dissolved with an acid sequence to obtain AEGs [22]. The first step of the acid dissolution sequence was performed with a non-oxidizing polyprotic acid, 
for which the graphite phase is immune, to dissolve and complex Fe. In this step, Si forms an amorphous phase, mainly composed by phosphosilicates, which were removed by a dilute solution of a strong acid. Then, the resulting porous graphite was subsequently washed with distilled water and ethyl alcohol in order to remove the remaining acid solution. The resulting porous graphite was then washed with distilled water and ethyl alcohol, in order to remove the remaining acid solution. The crystalline structure was examined by X-ray diffraction (Philips 3020 Goniometer with a PW 3710 controller) using $\mathrm{Cu} \mathrm{K} \alpha$ radiation at $35 \mathrm{kV}$ and $40 \mathrm{~mA}$, between $3^{\circ}$ and $70^{\circ}$ with a step of $0.04^{\circ}$ and a counting time of $2 \mathrm{~s} /$ step. The morphological and chemical analyses of the AEGs were performed by means of a scanning electron microscope (SEM) FEI Quanta 200. The determination of the surface area was performed by Brunauer-Emmett-Teller (BET) analysis with $\mathrm{N}_{2}$ absorption isotherms, by using Micromeritics ASAP 2020 equipment.

\subsection{Electrochemical AEG Test: $\mathrm{Li}_{-} \mathrm{O}_{2}$ Battery}

A home-made Teflon body closed with standard high vacuum components was used as electrochemical cell. Its design was based on the Giessen battery [23]. This cell ensures a fixed and uniform pressure, simple cell assembly, and easy gas flow around the electrodes during the addition of oxygen.

The battery consisted of a lithium metal foil anode (Gelon Energy Co., Vimengroad Lanshan, Rizhao, China), with $0.8 \mathrm{~cm}^{2}$ surface area and $0.45 \mathrm{~mm}$ thickness, a $260 \mu \mathrm{m}$ thickness fiberglass separator (FilterLab MFV1, Filtros Anoia S.A., Barcelona, Spain) wetted with $0.1 \mathrm{~mL}$ of electrolyte: $1 \mathrm{M}$ lithium bis-(trifluoromethanesulfonyl)-imide (LiTFSI), 99.95\% in triethylene glycol dimethyl ether (Triglyme) (both, Sigma-Aldrich, St. Louis, $\mathrm{MO}, \mathrm{USA})$. Finally, small sheets of the studied material $\left(\approx 0.3 \mathrm{~cm}^{2}\right)$ were used as a cathode. A stainless-steel disc mesh was used as a current collector. All $\mathrm{Li}_{2} \mathrm{O}_{2}$ cells were assembled in an argon-filled glove box (MBRAUN Unilab Pro SP, Garching, Bavaria, Germany). Electrochemical measurements were performed at $23^{\circ} \mathrm{C}$ using a multi-channel potentiostat (Bio-Logic VMP3, Seyssinet-Pariset, France). Oxygen was forced to pass through the cell for $60 \mathrm{~s}$ before starting electrochemical measurements.

Cyclic voltammetries were carried out, working in an electrochemical window, between 2.0 to $4.6 \mathrm{~V}$ at $0.02 \mathrm{Vs}^{-1}$ in successive cycles. On the other hand, in order to determine the useful life, successive cycles at constant current with a fixed cut-off in potential and capacity were performed. During discharge, a negative current (reduction current) was applied until the potential of the cell between the electrodes reached $2.0 \mathrm{~V}$, or until the capacity of the cell reached $0.5 \mathrm{mAh} \mathrm{cm}^{-2}$. Then, the charge was carried out by means of applying a positive current (oxidation current), until the potential of the cell reached $4.6 \mathrm{~V}$, or until the capacity of the cell reached $0.5 \mathrm{mAh} \mathrm{cm}^{-2}$. This cycle was repeated, as long as it was observed that the obtained capacities were close to the set capacity value, in this case $0.5 \mathrm{mAh} \mathrm{cm}^{-2}$.

Redox mediators synthesis: the $\mathrm{Ru}(\mathrm{bpy})_{3}\left(\mathrm{ClO}_{4}\right)_{2}$ was synthetized by a metathesis reaction between the metal complex $\mathrm{Ru}(\mathrm{bpy})_{3} \mathrm{Cl}_{2}$, (Aldrich-Chemical) in presence of an excess of sodium perchlorate $\left(\mathrm{NaClO}_{4}\right.$, purity $>99 \%$, Fluka), under constant agitation. An orange solid was obtained, which, at the same time, was filtered and purified by recrystallization, in a 50:50 mixture of acetonitrile/benzene, and then it was dried in a vacuum oven at $120^{\circ} \mathrm{C}$ for $24 \mathrm{~h}$.

\section{Results}

3.1. SEM

Figure 2a shows a monolithic wedge to illustrate that the extraction technique maintains the integrity of macroscopic pieces in the required shape and size. In Figure $2 b$, the image of the microstructure of the AEG obtained is shown, while in the upper right insert, the electrode with the dimensions required to be mounted on the battery is observed. 

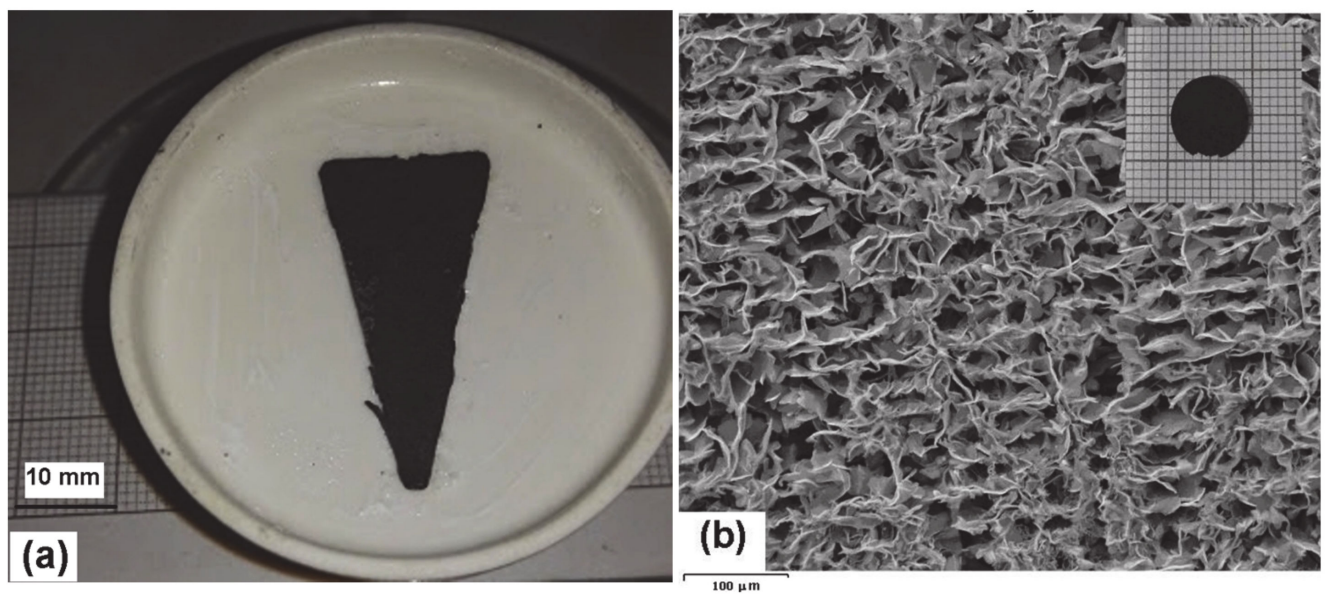

Figure 2. (a) Monolithic wedge; (b) aero-eutectic graphite (AEG) extracted from laminar graphite Type D (LDG) with insert on the upper right with the dimension of electrode of $\mathrm{Li}^{-} \mathrm{O}_{2}$ battery.

Figure 3 corresponds to AEGs of LAG and CG that were obtained after the chemical attack, while Figure 4 shows the AEG from LDG that was probed in $\mathrm{Li}-\mathrm{O}_{2}$. The transition between zones with different spacing, as shown in Figure 4c, is explained in the next section, called Discussion.
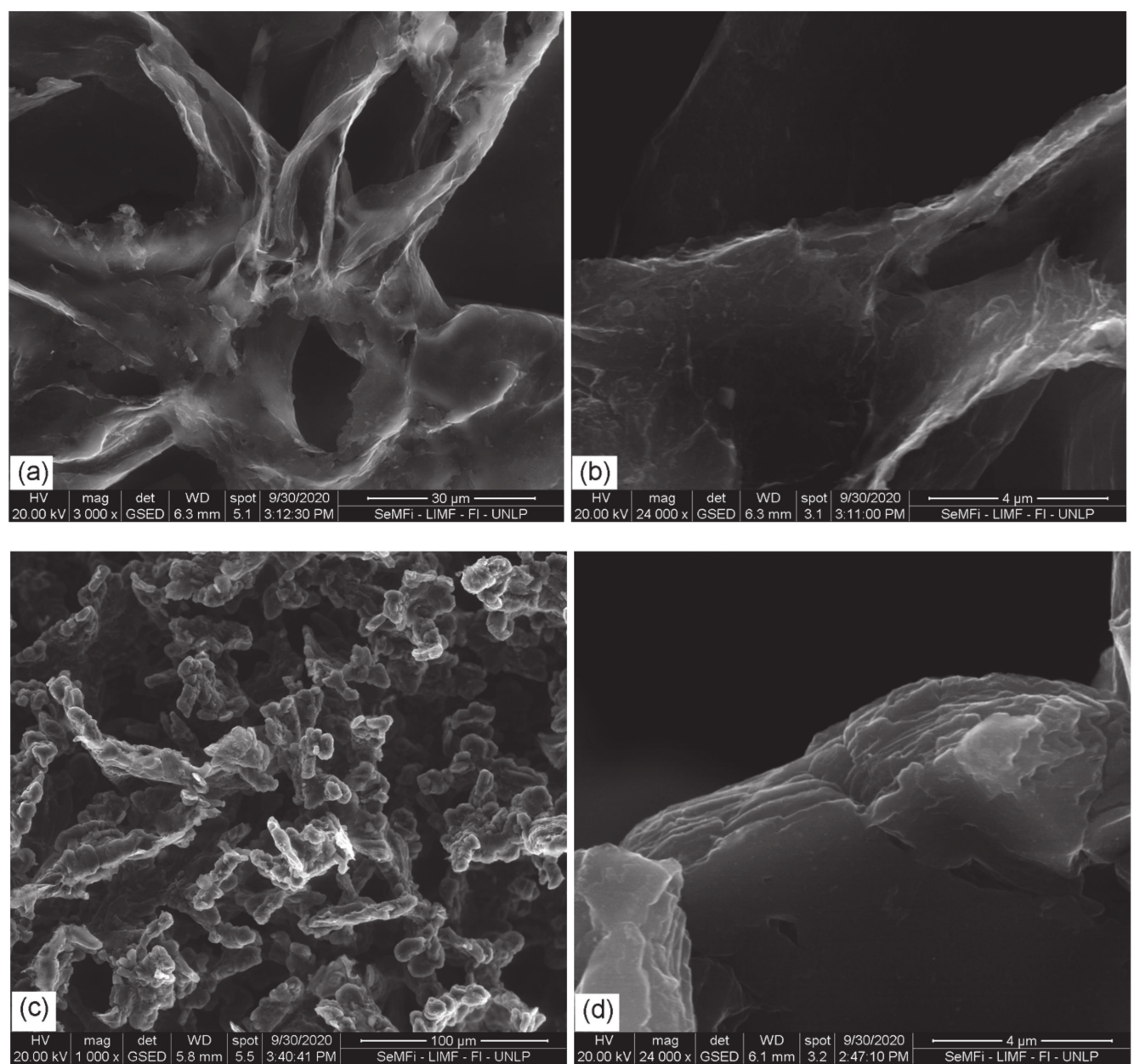

Figure 3. SEM images of AEGs obtained at two different magnifications from: LAG (a) and (b); compacted graphite (CG) (c) and (d). 

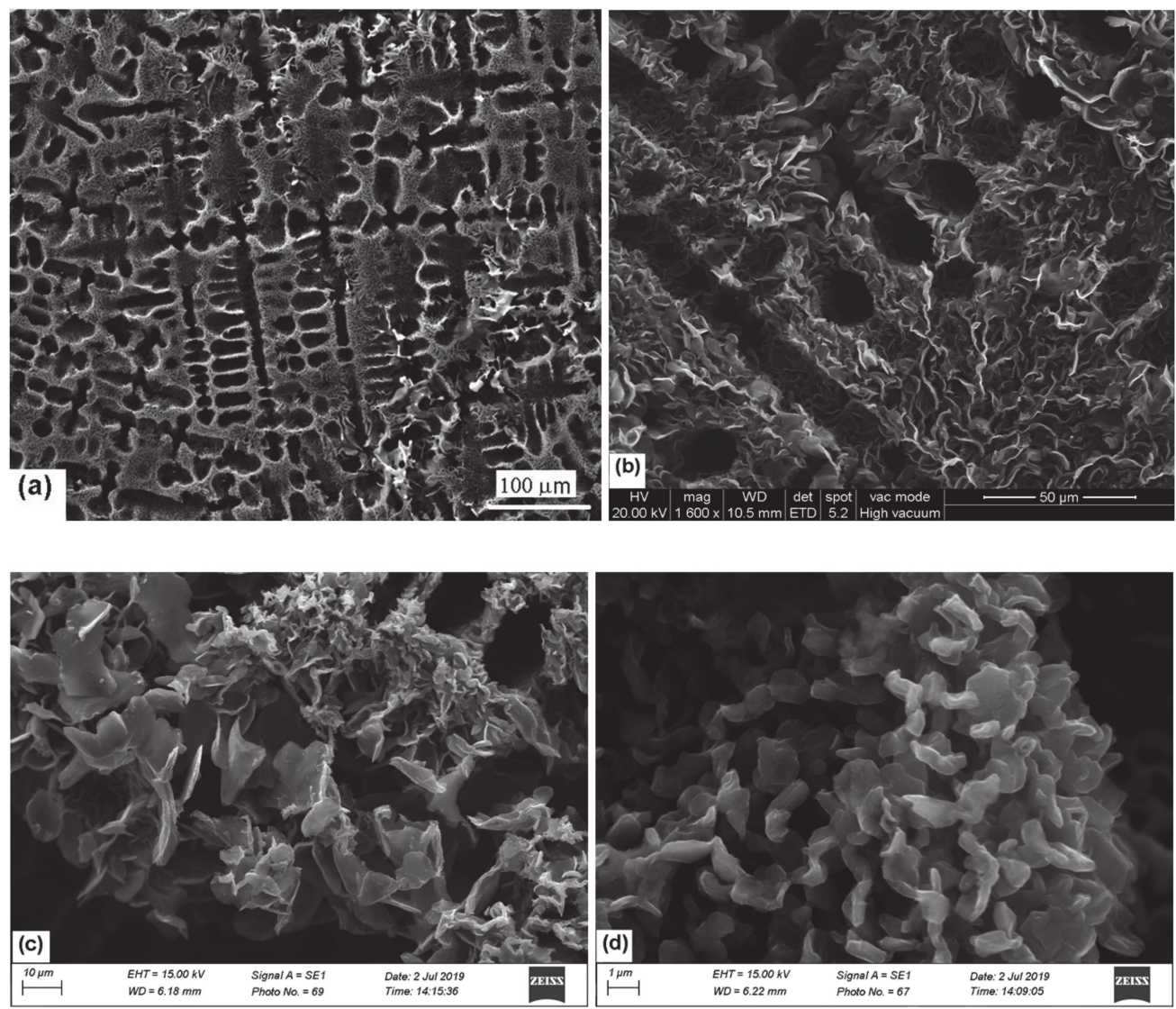

Figure 4. SEM images of the AEG-LDG that was tested in $\mathrm{Li}-\mathrm{O}_{2}$, at four different magnifications: (a) Field view of AEG-LDG; (b) Quasi-cylindrical channels left by the dissolved matrix; (c) Transition from LDG to another finer LG; (d) Detail of the finer LG.

Figure 5 shows a record of an infrequent "worm's" fracture event in a CG Charpy assay. Note the narrow and, probably, very extensive slits left by the imperfect stacking of foliate dendrites. See Discussion for more details.

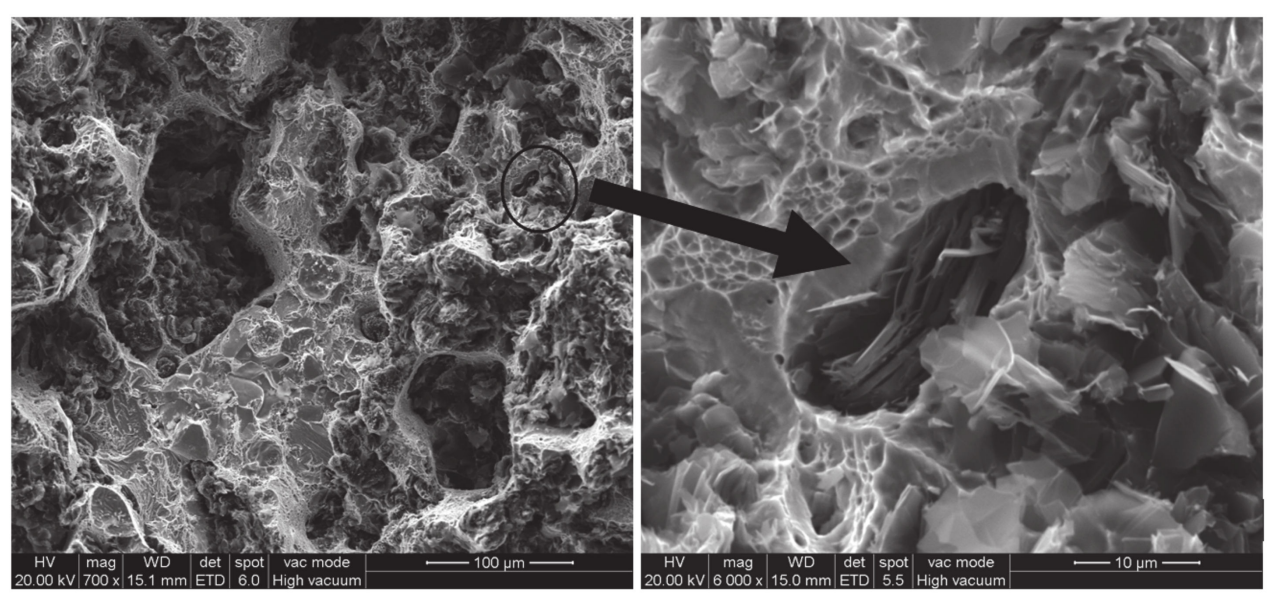

Figure 5. SEM Images of CG breakage caused in a Charpy impact test.

\subsection{BET and X-Ray Diffraction}

BET analysis of the surface area of the three AEGs analyzed are reported in Table 1. 
Table 1. Surface area determined by Brunauer-Emmett-Teller (BET) analysis of the graphite morphologies.

\begin{tabular}{cc}
\hline Graphite & Area \\
\hline Type LAG & $83.390 \mathrm{~m}^{2} \mathrm{~g}^{-1}$ \\
Type LDG & $89.670 \mathrm{~m}^{2} \mathrm{~g}^{-1}$ \\
CG & $106.277 \mathrm{~m}^{2} \mathrm{~g}^{-1}$ \\
\hline
\end{tabular}

The AEG from CG presented the highest specific surface of graphite, compared to type AEG from LAG and LDG. Despite that LAG and LDG have very big flakes surfaces, their specific areas were the smallest. The reason may be attributed to the fact that the AEGs from LAG and LDG are formed by structures much finer, but building with nonporous walls of G. Instead, as CG is constituted by a large quantity of stacked foliated dendrites, it has an intrinsic porosity that does not exist in laminar $\mathrm{G}$ types, as discussed later.

Figure 6 shows the X-ray diffraction pattern of AEG-LDG used in the battery, where it can be seen the peaks that correspond to crystallographic planes of $G$, and a small peak that is ascribed to $\mathrm{Cu}^{0}$.

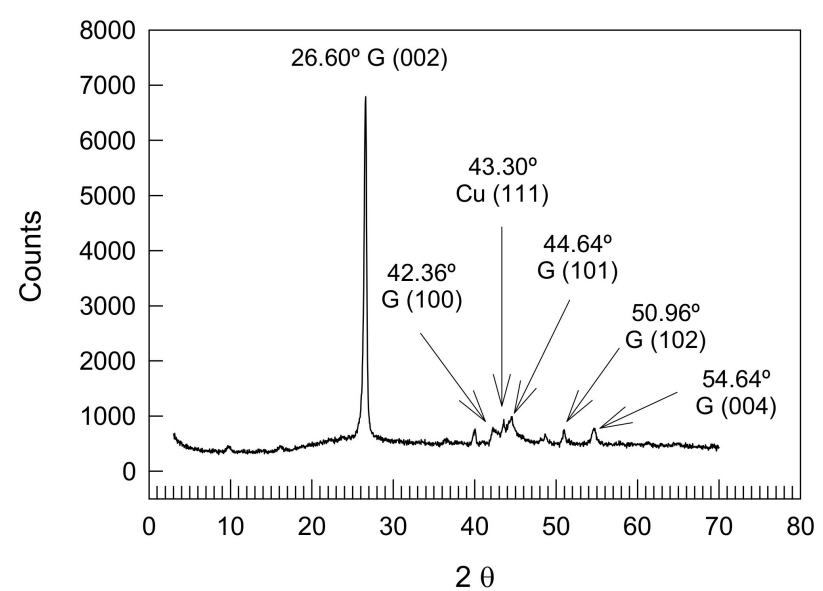

Figure 6. XRD pattern of AEG-LDG.

\subsection{Cyclic Voltammetry and Discharging Profiles of $\mathrm{Li}_{-} \mathrm{O}_{2}$ Battery With LDG-AEG Cathode}

Before being cycled in the $\mathrm{Li}-\mathrm{O}_{2}$ battery, the cathode was subjected to a cyclic voltammetry test, both in argon and in oxygen. The results are shown in Figure 7.

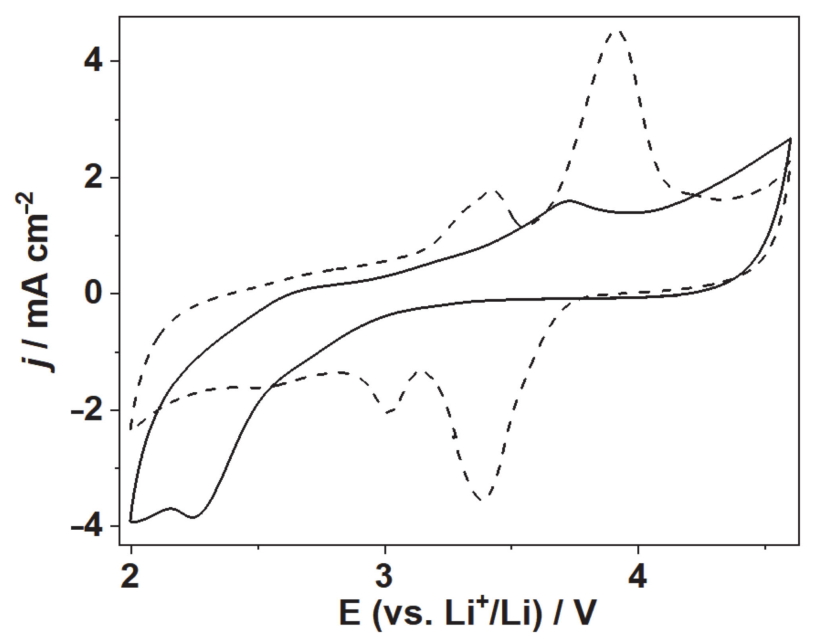

Figure 7. Cyclic voltammetry performed at $0.02 \mathrm{~V} \mathrm{~s}^{-1}$ for $1 \mathrm{M}$ lithium bis-(trifluoromethanesulfonyl)imide (LiTFSI), Triglyme solution in argon atmosphere (dotted line) and in oxygenated cell (continuous line). 
To test the performance of the AEG as a $\mathrm{Li}-\mathrm{O}_{2}$ battery cathode, successive dischargecharge cycles were performed. Figure 8 shows the results obtained from being used in either the presence or the absence of a redox mediator.
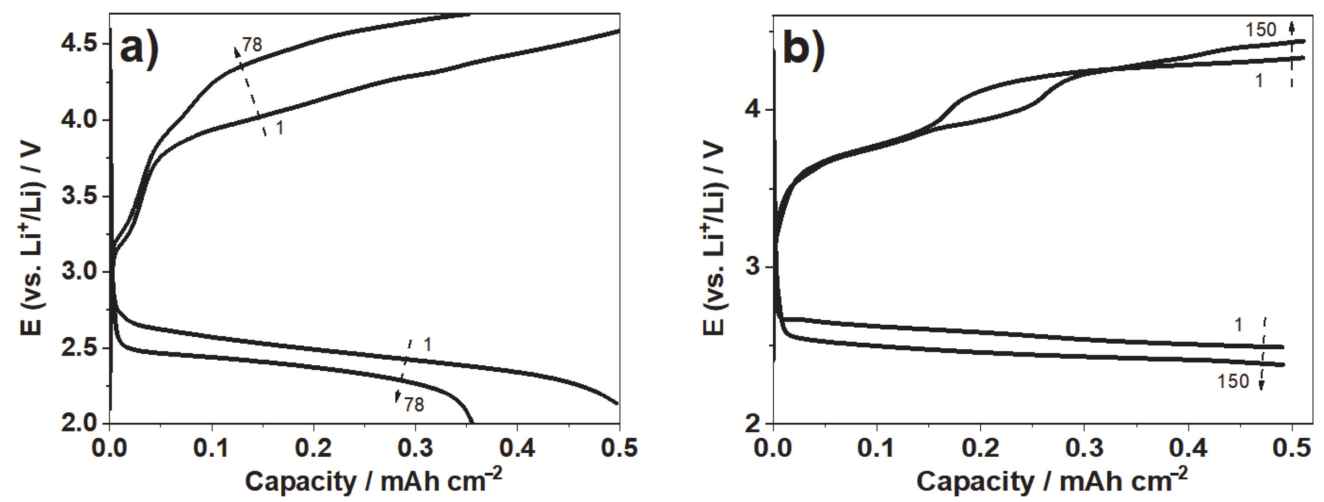

Figure 8. $\mathrm{Li}_{2} \mathrm{O}_{2}$ discharge-discharge profiles of $1 \mathrm{M}$ LiTFSI in Triglyme electrolyte in oxygenated cell using AEG as a cathode, (a) without and (b) with $5 \mathrm{mM} \mathrm{Ru}(\mathrm{bpy})_{3}\left(\mathrm{ClO}_{4}\right)_{2}$. Current density of $0.1 \mathrm{~mA} \mathrm{~cm}^{-2}$.

Discharge limited to $0.5 \mathrm{mAh} \mathrm{cm}^{-2}$. The cycle number is indicated inside.

\section{Discussion}

\subsection{Evidence of Non-Faceted Growth in LG}

The Fe-C system has been classified as faceted $(\mathrm{G}) /$ non-faceted ( $\gamma$-austenite), due to the high fusion entropy of $\mathrm{G}$ and to the fact that it produces an irregular structure. The following discussion is intended to illustrate that this is not the case.

Figure 9 corresponds to a frozen front of LAG, solidified under restricted conditions, according to a previous work [14]. The lamellae $G$ are shown, leading the front during coupled and cooperative eutectic, growth, and maintaining a triple contact line with $\gamma$. After freezing, they initiate a rapid growth into the liquid following the new direction of the driving force exhibiting a marked ripple, typical of non-faceted growth. Then, copious and continuous conversion to undercooled graphite, emanating from the tips of the original flakes can be observed.

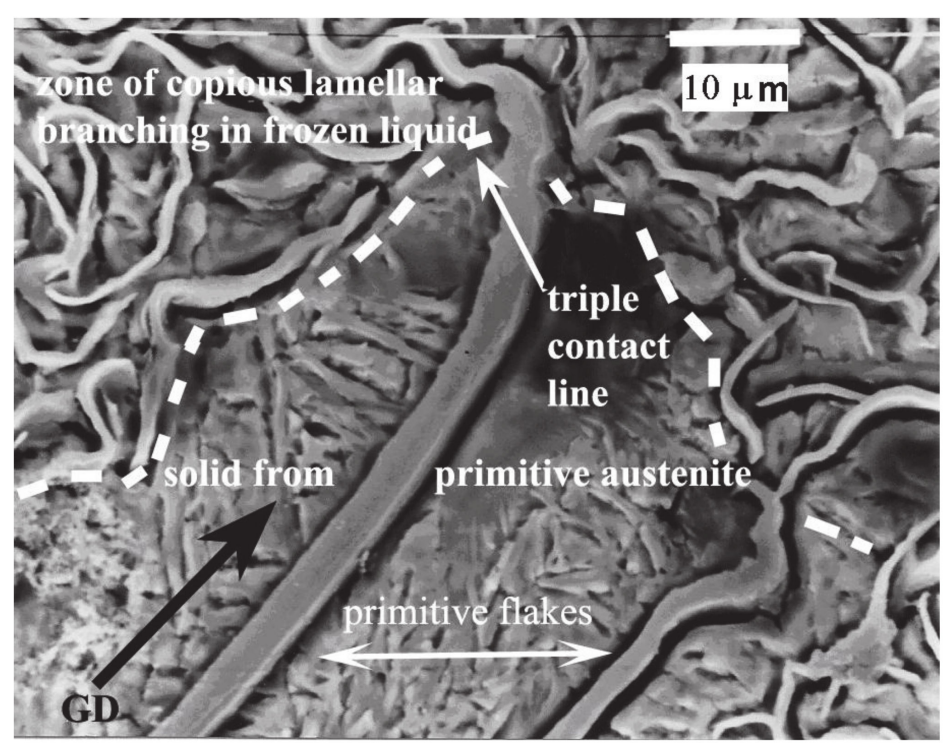

Figure 9. Frozen interface in laminar graphite Type A (LAG) shows the wavy appearance of the primary sheets once they supercool and become thinner and curlier. Special attention should be paid to the absence of pores in the section of these morphologies. 
The sequence of Figure 10 corresponds to another experience in which the freezing procedure was more abrupt and was performed closer to the interface. The sequence reveals details of the successive stages in which transformation of LAG to undercooled G runs through. In this case, the base alloy was alloyed with $6 \% \mathrm{Ni}$, in order to determine the texture growth of the laminar eutectic [24], the significance of which is later discussed.

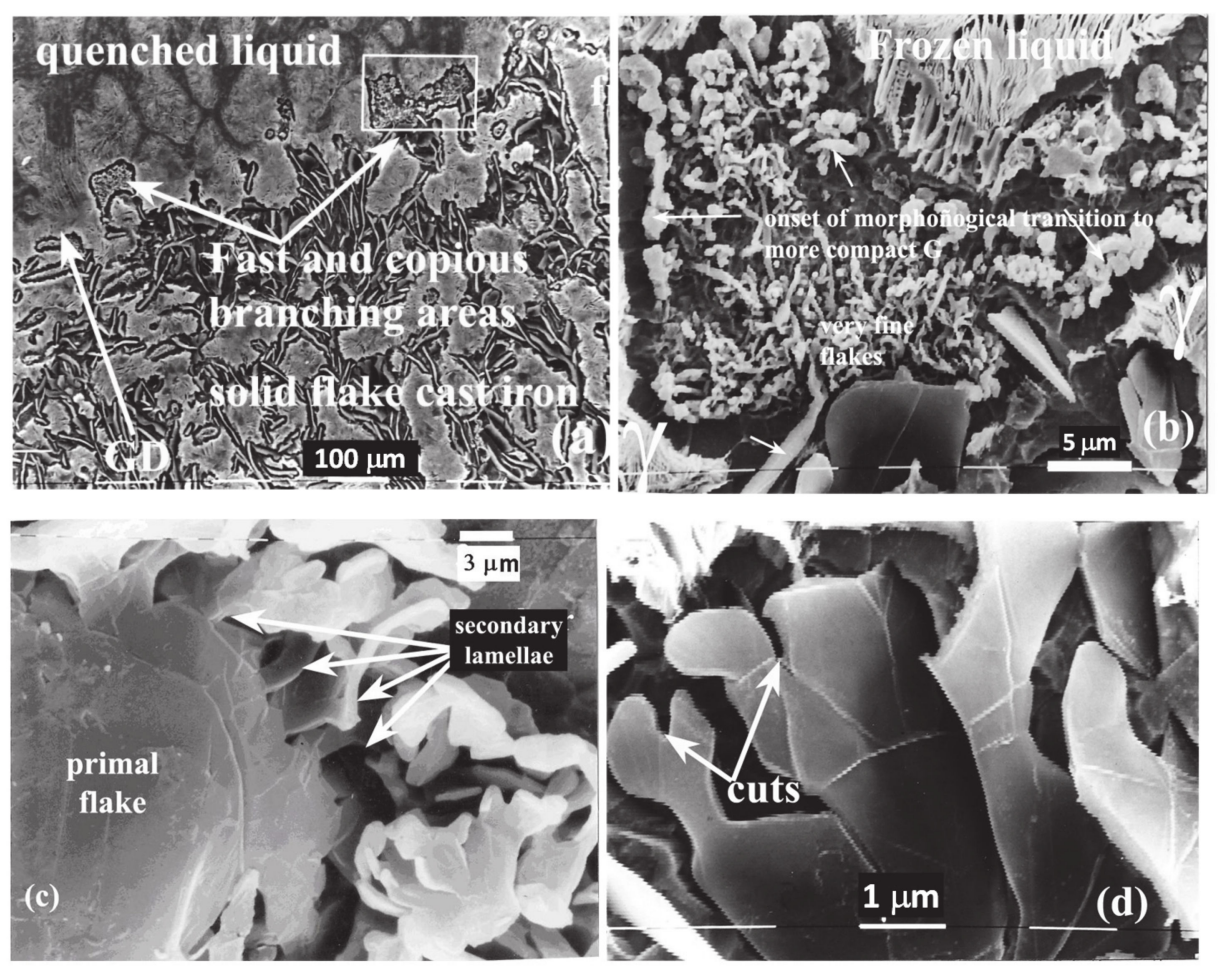

Figure 10. SEM images of the sequence of transition from LAG to undercooled G; (a) panoramic view of LAG eutectic front/ liquid interface; (b) magnification of marked zone of (a); (c) detail of branching; (d) details of twinned undercooled G showing intense twinning.

In Figure 10a, it is seen that most of the primitive solid/liquid interface is stopped when the liquid abruptly solidifies to ledeburite in the metastable system. However, in several areas, such as the one marked, before this happens, there is rapid and copious branching of the LAG. In Figure 10b, within this selected area, the continuity of the transition between the LAG and supercooled G is shown, while in Figure 10c, the branching process is observed. The original flake shows no faults, until a boundary from which an intensely-twinned zone appears. This is followed by the emergence outside the primitive basal plane of numerous secondary lamellae with quasi regular spacing. There is no doubt that branching takes place in the wide largest dimension of the primal flake and not in the smallest one, as has been proposed in the growth model with faceted $G$ by Magnin and Kurz [25]. Finally, Figure 10d clearly shows that G secondary lamellae are non-faceted, since their habit closes with rounded shapes, and there are no signs of singular prismatic planes in it. Each secondary lamellae is thin, and features intense twinning, as predicted by Hellawell [7].

In the results of the present work, the transition observed in Figure 4d from LDG to another finer LG could be explained by this mechanism. However, the transitions can be reversible, that is, from undercooled G to LAG. A typical example of this reversible transition occurs in laminar $G$ type $B$ (free-growing rosettes of $G$ ), in which the undercooled $\mathrm{G}$ in the center of the rosette is transformed into LAG in the periphery. It should not be ruled out that, in the aforementioned Figure 4, the very thin sheets would have nucleated on the surface of the primary dendrites, where carbon is intensely segregated, and would have transformed into thicker sheets in the channels, where the driving force would be 
less, due to latent heat released and the least amount of constitutional undercooling promoted by carbon. The key to the inverse transformation is that the two eutectic phases can reestablish the $\gamma / \mathrm{G}$ interface with preferential growth orientations. The crystallographic coupling relationships between the phases are reproduced below and have been described in an earlier work [24]. In conclusion, we consider that the LG eutectic belongs to the non-faceted/non-faceted class, and its growth proceeds through a cooperative and coupled mechanism.

Preferential growth ratios of LG in the interface $\gamma / G$ :

Majority proportion; $\left.<100\rangle_{\gamma} / /<11.0\right\rangle_{\mathrm{G}} / /$ growth direction,

A significant proportion; $<10.0>_{\mathrm{G}} / /$ growth direction,

Lesser extent; $\{10.1\}_{\mathrm{G}} \perp$ growth direction.

Figure 11 shows two examples of supercooled Gs from LDG and LEG showing evidence of non-faceted growth, including $n-f$ dendrites. The particle in the center of Figure 11a, with a very well-defined cubic habit (probably $\mathrm{TiC}$ ), leaves no doubt that at this magnification, prismatic planes should be detected. It can be concluded that the $G$ phase has a non-faceted growth, therefore, adjusting its curvature easily, according to the scheme proposed in Figure 12 to maintain preferential common interface relationships with austenite. As a consequence, it is expected that the sheets, whatever their size and shape may be, will turn out, from a crystalline point of view, fairly perfect and without intrinsic porosity. Particularly noteworthy is the way in which the $G$ sheets manage to easily surround the austenite branches following their curvature, obeying the driving force that nourishes them, which, in this case, is the maximized accumulation of $C$ there. The only pores in the resulting AEG will then correspond to those left behind by the intricate continuous austenite network when this phase is finally removed.
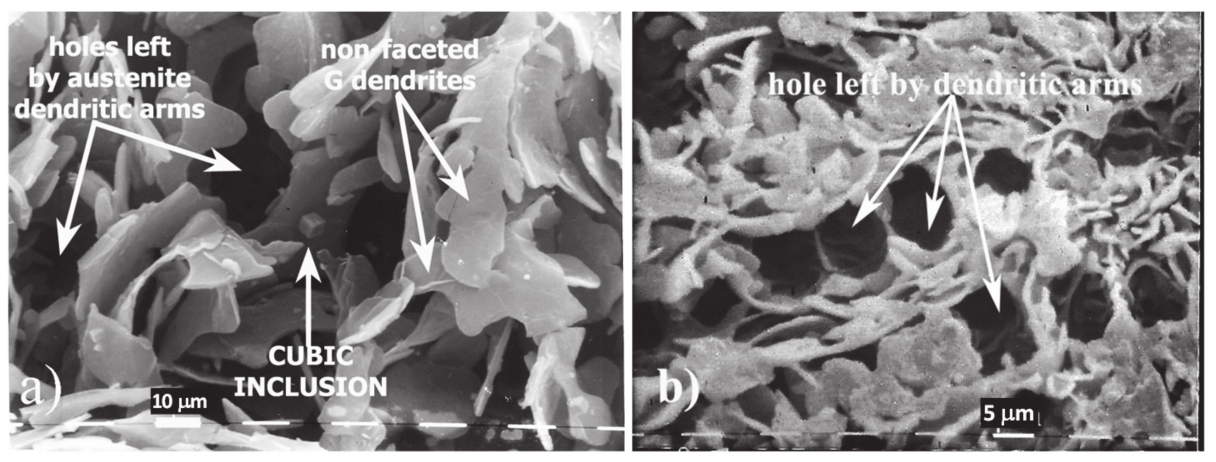

Figure 11. SEM images from non-faceted $G$ of graphite lamellas of gray cast iron, (a) type D and (b) type E.

\subsection{Evidence of Faceted Dendritic Growth in GC}

Curiously, the CG morphologies have been, and are still, called vermicular because under optical microscopy (OM) observation, without or with a slight etching, they look similar to "worms", and their limits look smooth and rounded. However, Figure 13a, tacked after deep etching procedure, shows a lateral surface view that reveals the surface clearly faceted of the "worm" (see insert in the lower right corner for more details). So, non-faceted appearance under OM is very misleading. In Figure $13 \mathrm{~b}$, foliated dendrites with two helical dislocations emerging on basal plane are shown. 


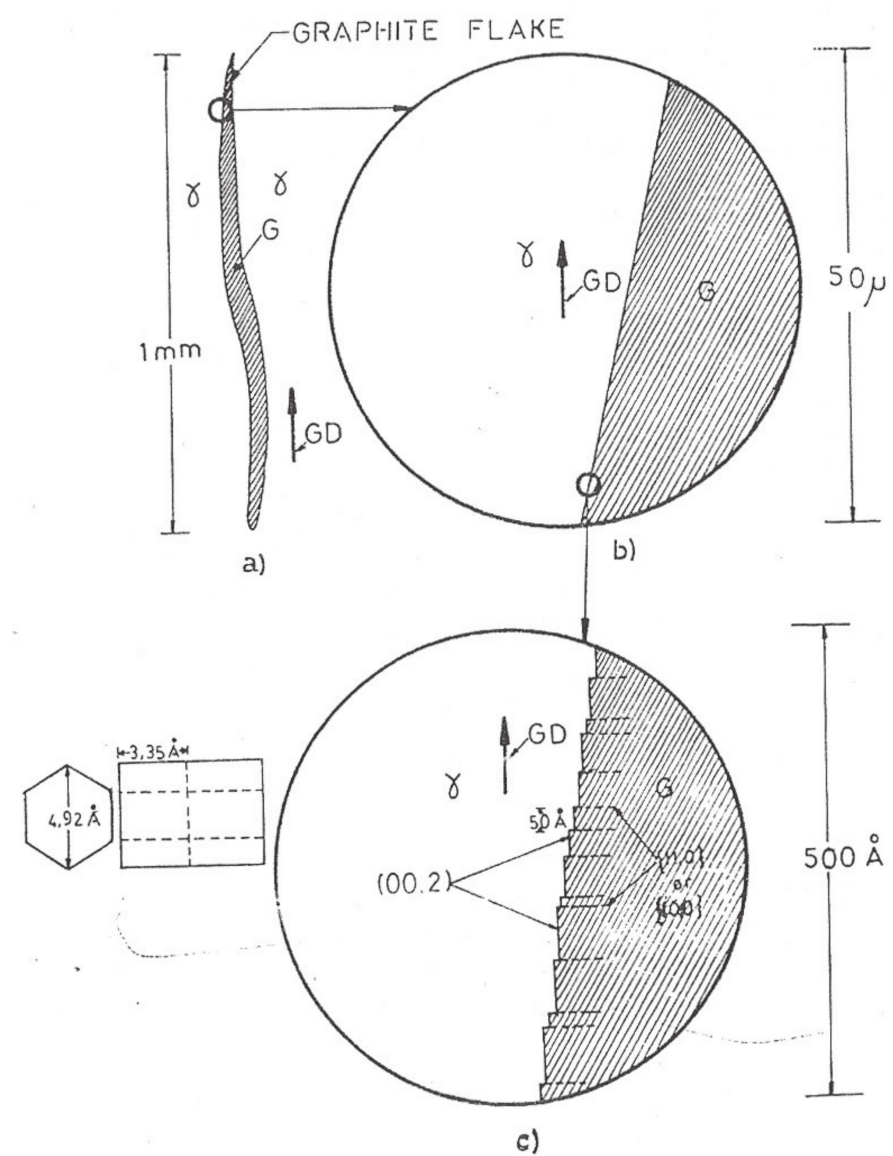

Figure 12. (a-c) This model shows curved basal plane of lamellar graphite (LG) growing with no-faceted interface.
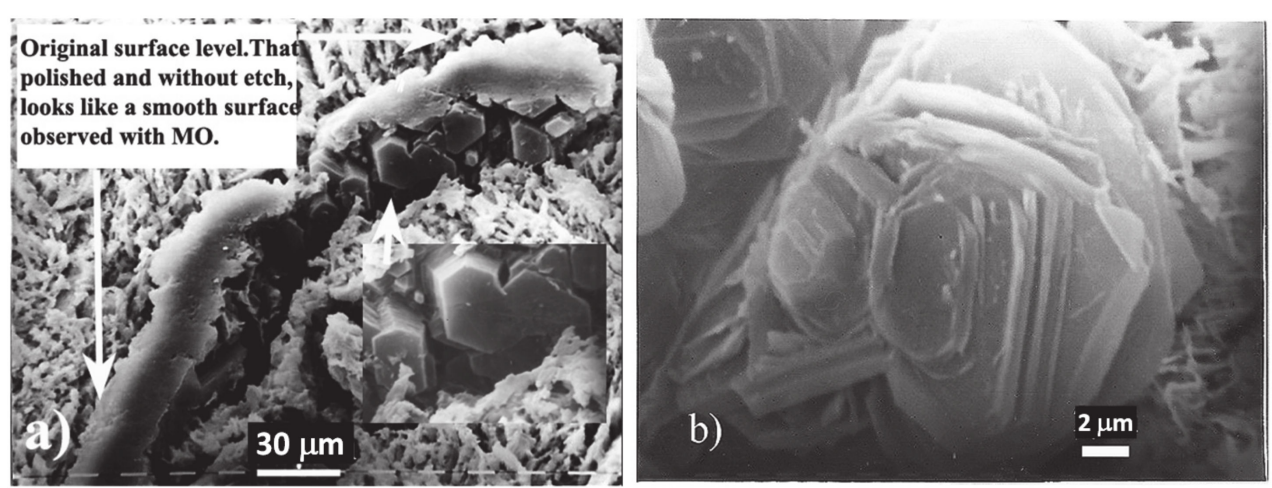

Figure 13. SEM images of: (a) CG from a grain boundary, showing noticeable faceted aspect in deep etched lateral walls. Instead, the upper plane looks much more rounded; (b) foliated dendrites with two helix dislocations emerging on basal plane.

The strong faceted growth that created the prismatic pillars shown in detail in the insert of Figure 13a is likely the result of activation of helix dislocations such as those illustrated in Figure 13b. Due to the very low solidification rate, they grew with a long time of permanence in contact with highly-supersaturated liquids typical of grain boundaries before being compacted by austenite. In the cited work [15], it is shown that without changing the imposed gradient or the growth rate, by the single addition in situ of spheroidizing reagents in the melt just in front of the LAG growing interface, a continuous transition was produced from seeds of laminar A to specimens of the "vermicular" variety. The transition is attributed to the thermodynamic impossibility of retaining the common $\gamma / \mathrm{G}$ interface 
once surface active agents (such as $\mathrm{S}$ and $\mathrm{O}$ ) have been removed by chemical reaction. Thus, the growth of the eutectic divorces and becomes uncoupled, yet it still continues to be cooperative. $G$ solidifies free in the liquid, in the form of faceted crystals identified as foliate dendrites, which are schematically presented in Figure 1.

As the solid fraction increases, G crystals contained in liquid channels are gradually squeezed and compacted by the solid walls of its eutectic pair. For this reason, the so-called worms are actually compacts of myriad G foliated dendrites; hence CG is more suitable to name the variety. Given the thinness of the faceted leaflets, it would be expected that those located in direct contact could partially copy the non-faceted shapes of the walls of $\gamma$. However, a detailed observation will easily reveal their faceted nature. The shape and size of the "compacts worms" will depend on the shape and size of the channels where the austenite has confined and shaped them. Consequently, there will be a grain border, with cellular and interdendritic CG of different scales [15]. Figure 14a,b show compacted graphite formation during the freeze of restricted solidification during the active period of modifiers. In Figure 14c, a foliated dendrite compaction model is presented to explain the formation of GC varieties, and in Figure 14d, the resulting "defective" GC is shown. If it is compared with the appearance of the cracks observed in the CG of the fracture illustrated in Figure 5 [26], it can be seen that they are practically identical; however, as in $14 \mathrm{~d}$, there has been no mechanical stress, the copious internal cracking observed in both cases would not have a mechanical origin, and it is a corroboration that this type of "cracks" are formed during solidification itself, and do not disappear.

At this point, some important and novel observations about CG could be highlighted from a perspective that is not oriented towards mechanical properties, but it is very important to predict and take advantage of the properties of AEG-CG for certain nontraditional applications, such as its use in $\mathrm{Li}-\mathrm{O}_{2}$ batteries presented in this work.

If we proceed to analyze the evidence in Figure 15, just by looking at the upper left corner of the image, it is evident that a possible twinning process allows a branch of this foliated dendrite to rotate out of the plane of the rest of the crystal. This is not illustrated, and is not predicted in the simple model of foliated dendrites of Figure 1. In case this happens, and if we wanted to make a compaction of a set of foliated dendrites, for example, pushing the crystals that are seen in Figure $1 \mathrm{~b}$ in a direction normal to that of Figure 1a, the rotated parts will prevent good stacking and high compaction ratio. On the other hand, when viewing the entire Figure 15, the full-faceted nature of the crystal is revealed through the steps due to twins of rotation and prismatic habit shapes with their characteristic angles. It is also observed that the saturation was enough to give rise to twodimensional (2D) nucleation on the basal plane. As 2D nucleation becomes more prevalent, an inhomogeneous thickening on the plane would be expected, and this again means that stacking will be more difficult. Finally, Figure 13b shows the appearance of helical dislocations in the basal plane, which also produces local thickening, and is very likely to cause the hexagonal prisms seen in Figure 13a, as already mentioned. The result will again be to make more difficult, or avoid, good stacking. All these peculiar characteristics of the real $\mathrm{G}$ foliate dendrites, that show the differences with the dendrites schematized in Figure 1, contribute to support the central hypothesis of this work, based on the fact that the compaction of graphite foliate dendrites would never be very effective, as it would generate a significant fraction of empty space between them. Consequently, part of the melt could be trapped inside the worms and, when the matrix is removed, a very significant intrinsic porosity, probably on a mesopore scale, could remain in the GC and become a great advantage for the three-dimensional self-supporting and self-integrated AEG-CG electrode. 

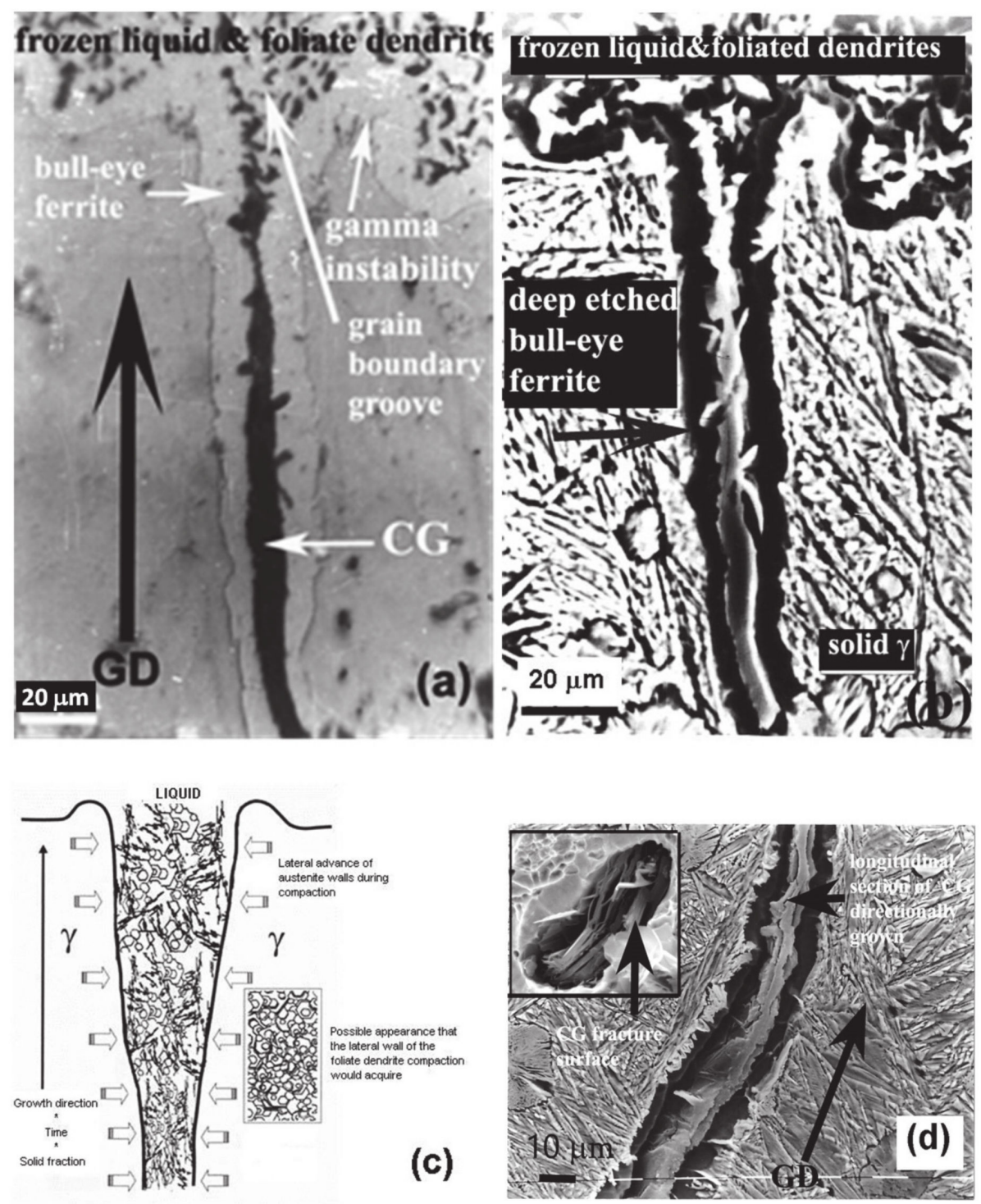

Figure 14. (a) Optical microscopy (OM) frozen interphase of growing CG; (b) idem SEM with deep etching; (c) compaction model; (d) CG showing compaction defects analogous to those showed on the fracture of Figure $5 b$.

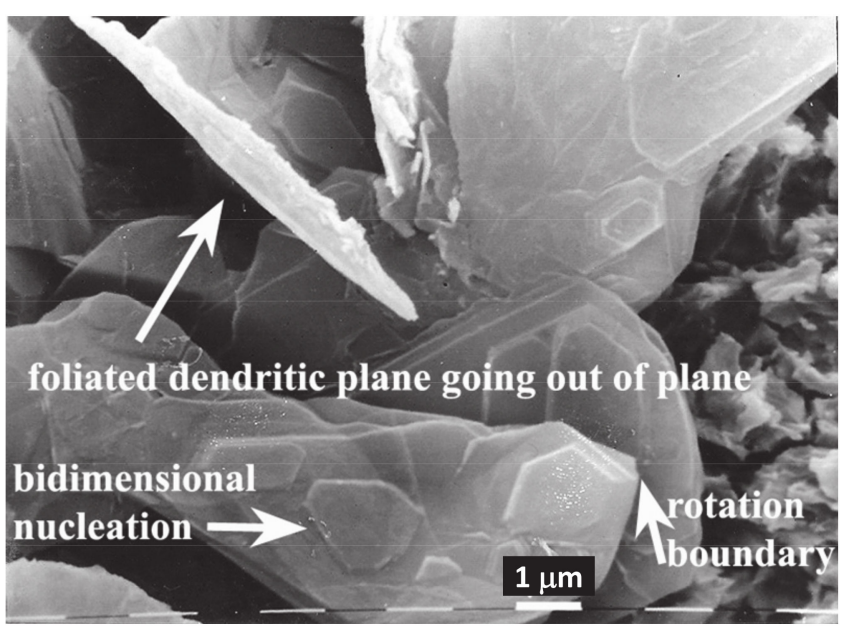

Figure 15. Foliated dendrite. 
The preceding discussion explains why CG exhibited the highest BET specific graphite surface, compared to the LAG type and the LDG type.

On the other hand, it should be noted that the proportion of specific surface associated with prismatic planes should be higher than in AEG-LG, which would be important for some functions of the electrodes of some Li batteries $[27,28]$. Future work is expected to determine the specific surface of prismatic planes, as well as the type and size of pores.

\subsection{AEG As Cathode in $\mathrm{Li}^{-\mathrm{O}_{2}}$ Battery}

The operation of a $\mathrm{Li}-\mathrm{O}_{2}$ battery implies oxygen reduction and evolution reactions (ORR and OER, respectively), during charge and discharge processes. These heterogeneous reactions require three different phases: the oxygen gas, the liquid non-aqueous electrolyte, where $\mathrm{O}_{2}$ and $\mathrm{Li}^{+}$are dissolved, and the solid cathode.

It is important to note how the distribution of pores is relevant in the improvement of the efficiency and cyclability of batteries, because their contact with the liquid (electrolyte) and gas (oxygen) phases would facilitate a good ionic transport. In this case, an open macroporous network is needed $[29,30]$.

A cyclic voltammetry test was first conducted in order to evaluate the performance of the AEG cathode. Before oxygen purge, the cell filled with argon (from the glove-box) was electrochemically tested, in which was not observed a typical voltammetry ORR signal (see Figure 7). However, it is possible to see two reversible redox couples at $3.2 \mathrm{~V}$ and $3.7 \mathrm{~V}$, probably originating from the titanium compounds and copper, which are present in the AEG. On the other hand, after oxygen purge, the ORR and the OER process take place at the usual potential values (starting close to $2.7 \mathrm{~V}$ and $3.2 \mathrm{~V}$, respectively), as shown in Figure 7, where the position and the shape of the peaks are similar to those reported in previous works on $\mathrm{Li}^{-} \mathrm{O}_{2}$ cells, in similar conditions [31,32]. According to these results, it may be inferred that the contact between the electrolyte and the AEG material is suitable enough to work as $\mathrm{Li}-\mathrm{O}_{2}$ cells cathode.

During the OER in oxygen atmosphere, it can be seen a broad oxidation peak at $3.7 \mathrm{~V}$, which is usually attributed to the oxidation of lithium peroxide particles of different sizes [33].

In order to test the AEG-LGD material as $\mathrm{Li}^{-} \mathrm{O}_{2}$ batteries cathode, galvanostatic discharge-charge cycles with a cut-off fixed at $0.5 \mathrm{mAh} \mathrm{cm}^{-2}$ were carried out at a typical current density of $0.1 \mathrm{~mA} \mathrm{~cm}^{-2}$. The potential vs. capacity curve of Figure 8a during the first and the last discharge-charge cycle shows a typical battery profile, which is similar to previous reports using the same electrolyte $[34,35]$. Working under these conditions, the battery reaches seventy cycles before the loss of capacity starts to be significant.

The observed capacity fade could be attributed to the increased reaction potential beyond the cut-off voltage and the impossibility to remove all the ORR products deposited on the electrode surface, and also, the removal of byproducts generated during ORR, because highly reactive oxygen products react with the components of the cell. Among them, singlet oxygen is the main cause for parasitic reactions during cycling of aprotic lithium-oxygen batteries [36].

With the aim to decrease the charge potential, which both the electrodes and the electrolyte are exposed to, and in order to extend the battery cycling, an electro active compound was added to the electrolyte and tested as a redox mediator (RM) under the same conditions.

However, RM should fulfill the energetic requirement imposed by the thermodynamics, and also RM should have the capability to deal with the reduced reactive oxygen species (RROS), which are known for their reactivity with many organic substrates, reducing the useful life of the battery. In this context, redox couples that may have the potential to act as $\mathrm{Li}-\mathrm{O}_{2}$ battery $\mathrm{RMs}$ are coordination compounds derived from ruthenium. $\mathrm{Ru}$ complexes are known for their excellent photochemical and electrochemical properties, as well as for the flexibility that they have to tune their properties through the selection of different organic ligands. Thus, this kind of material has shown an outstanding performance in sev- 
eral applications, including electrochemical and photo electrochemical catalysis in energy conversion area for light-emitting devices, sensors, among others [37].

As may be seen in Figure $8 b$, through the use of $5 \mathrm{mM} \mathrm{Ru}(\mathrm{bpy})_{3}\left(\mathrm{ClO}_{4}\right)_{2}$, as $\mathrm{RM}$, it is possible to improve the battery cycling by having the same values of discharge potential and decreasing the recharge potential value. Finally, the $\mathrm{Li}_{-} \mathrm{O}_{2}$ battery with $\mathrm{Ru}(\mathrm{bpy})$ reached 150 cycles and still kept the fixed capacity value. In both cases, AEG-LDG showed a good performance in $\mathrm{Li}-\mathrm{O}_{2}$ battery.

Although more studies of stability and on the reaction mechanism of $\mathrm{Ru}(\mathrm{bpy})_{3}\left(\mathrm{ClO}_{4}\right)_{2}$ as $\mathrm{RM}$ are needed, it is clear that it can be used satisfactorily in $\mathrm{Li}-\mathrm{O}_{2}$ batteries.

\section{Conclusions}

Restricted solidification studies have proven that lamellar graphite (LG) grows in a non-faceted way in eutectic gray cast iron, while vermicular, or compact graphite (CG) does it as compacted faceted foliated graphite dendrites. This leads to vermicular graphite having a larger surface area than laminar varieties $\mathrm{A}$ and $\mathrm{D}$.

From these results, an aero-eutectic graphite (AEG) that optimizes its functions could be designed. In the case of the present work, it is considered that the performance of type D AEG, as a cathode of $\mathrm{Li}^{-} \mathrm{O}_{2}$ batteries, is satisfactory. For future works, it is contemplated to carry out tests with the compact graphite variety, taking into account its larger surface.

Author Contributions: Conceptualization: A.N.R.; data curation: A.N.R., A.Y.T. and R.W.G.; formal analysis: A.N.R., A.Y.T., F.F. and R.W.G.; funding acquisition: A.Y.T., F.F. and R.W.G.; investigation: A.N.R., A.Y.T., F.F. and R.W.G.; methodology: A.N.R.; project administration: A.N.R., F.F. and R.W.G.; resources: A.N.R. and R.W.G.; validation: A.N.R., A.Y.T. and F.F.; visualization: A.Y.T., F.F. and R.W.G.; writing—original draft: A.N.R., A.Y.T., F.F. and R.W.G.; writing—review and editing: A.N.R. and R.W.G. All authors have read and agreed to the published version of the manuscript.

Funding: This research received no external funding.

Institutional Review Board Statement: Not applicable.

Informed Consent Statement: Not applicable.

Data Availability Statement: Not applicable.

Acknowledgments: The authors also give special thanks to the Comisión de Investigaciones Científicas de la Provincia de Buenos Aires (CICPBA), Centro de Investigación y Desarrollo en Materiales Avanzados y Almacenamiento de Energía de Jujuy (CIDMEJu) and Facultad de Ingeniería de la Universidad de Buenos Aires (FIUBA) for their financial support to carry out the experimental works.

Conflicts of Interest: The authors declare no conflict of interest.

\section{Abbreviations}

$\begin{array}{ll}\text { AEG } & \text { Aero-Eutectic Graphite } \\ \text { AEG-CG } & \text { Aero-Eutectic graphite from compacted graphite } \\ \text { AEG-LGD } & \text { Aero-Eutectic graphite from Type D graphite } \\ \text { BET } & \text { Brunauer-Emmett-Teller } \\ \text { CG } & \text { Compacted graphite } \\ \text { FCC } & \text { Face centered cubic } \\ \text { LAG } & \text { Lamellar graphite Type A } \\ \text { LDG } & \text { Laminar graphite Type D } \\ \text { LEG } & \text { Lamellar graphite Type E } \\ \text { LG } & \text { Lamellar graphite } \\ \text { LG-AEG } & \text { Aero-Eutectic graphite lamellar graphite } \\ \text { LiTFSI } & \text { Lithium bis-(trifluoromethanesulfonyl)-imide } \\ \text { MM } & \text { Morphological Modification } \\ \text { n-f } & \text { non-faceted } \\ \text { NG } & \text { Nodular graphite } \\ \text { OER } & \text { Oxygen evolution reaction }\end{array}$




$\begin{array}{ll}\text { OM } & \text { Optical microscopy } \\ \text { ORR } & \text { Oxygen reduction reaction } \\ \text { RM } & \text { Redox mediator } \\ \text { Triglyme } & \text { Triethylene glycol dimethyl ether } \\ \gamma & \text { Austenite }\end{array}$

\section{References}

1. Su, B.L.; Sánchez, C.; Yang, X.-Y. Hierarchically Structured Porous Materials: From Nanoscience to Catalysis, Separation, Optics, Energy, and Life Science, 1st ed.; Wiley VCH: Weinheim, Germany, 2012.

2. Gregorutti, R.W.; Tesio, A.Y.; Gómez-Cámer, J.L.; Roviglione, A.N. Synthesis and characterization of aero-eutectic graphite obtained by solidification and its application in energy storage: Cathodes for lithium oxygen batteries. Electron. Mater. $2020,1,3$. [CrossRef]

3. McNaught, A.D.; Wilkinson, A. Compendium of Chemical Terminology, 2nd ed.; The "Gold Book"; Blackwell Scientific Publications: Oxford, UK, 1997; ISBN 0-9678550-9-8. [CrossRef]

4. Holcombe, C.E. USAEC Oak Ridge Y-12 Plant, Report Y 1887; National Technical lnformation Service: Springfield, VA, USA, 1973.

5. Roviglione, A.N.; Hermida, J.D. Mechanism of formation of different cast iron graphite structures. In Proceedings of the 72nd National Conference of the Argentine Physical Association (AFA), San Carlos de Bariloche, Argentina, 28 September-2 October 1987.

6. Delavignette, P.; Amelinckx, S. Dislocation patterns in graphite. J. Nuclear Mater. 1962, 5, 17-66. [CrossRef]

7. Double, D.D.; Hellawell, A. Cone-helix growth forms of graphite. Acta Metall. 1974, 22, 481-487. [CrossRef]

8. Roviglione, A.N.; Hermida, J.D. Rhombohedral graphite phase in nodules from ductile cast iron. Proc. Mater. Sci. $2015,8,924-933$. [CrossRef]

9. Kelly, B.T. Physics of Graphite; Applied Science Publishers: London, UK, 1981.

10. Saratovkin, D.D. Dendritic Crystallization; Consultants Bureau Transl.: New York, NY, USA, 1959.

11. Liu, S.; Loper, C.R. The formation of kish graphite. Carbon 1991, 29, 547-555. [CrossRef]

12. Roviglione, A.N.; Biloni, H. Modificación de la morfología de crecimiento de la fase grafito durante la solidificación unidireccional de la fundición de hierro gris. PARTE I: "Solidificación Unidireccional. modificación in-situ, congelado de la interfaz SólidoLíquido y Caracterización de Microestructuras". In Actas Jornadas Metalúrgicas SAM'91; II ALAMET'91 ed.; Sociedad Argentina de Metales: Buenos Aires, Argentina, 1991.

13. Roviglione, A.N.; Biloni, H. Unidirectional solidification of cast iron: Morphological changes of graphite due to in-situ modification. In Proceedings of the Fifth International Symposium on the Physical Metallurgy of Cast Iron (SCI-5), Nancy, France, 3-5 October 1994; pp. 369-376.

14. Roviglione, A.N.; Hermida, J.D. A new unidirectional solidification method to study gray cast iron. Metall. Mater. Trans. B 2002, 33, 235-241. [CrossRef]

15. Roviglione, A.N.; Hermida, J.D. From flake to nodular: A new theory of morphological modification in gray cast iron. Metall. Mater. Trans. B 2004, 35, 313-330. [CrossRef]

16. Stefanescu, D.M.; Huff, R.; Alonso, G.; Larrañaga, P.; De La Fuenta, E.; Suarez, R. On the crystallization of compacted and chunky graphite from liquid multicomponent Iron-Carbon-Silicon-based melts. Metall. Mater. Trans. A 2016, 47, 4012-4023. [CrossRef]

17. ASTM A247-19. Standard Test Method for Evaluating the Microstructure of Graphite in Iron Castings; ASTM International: West Conshohocken, PA, USA, 2019. [CrossRef]

18. Park, J.S.; Verhoeven, J.D. Transitions between type A flake, type D flake, and coral graphite eutectic structures in cast irons. Metall. Mater. Trans. A 1996, 27, 2741-2753. [CrossRef]

19. Larrañaga, P.; Sertucha, J.; Loizaga, A.; Suarez, R.; Stefanescu, D.M. Gray cast iron with high austenite-to-eutectic ratio. Part IIIHigh strength, low hardness, high carbon equivalent gray iron with superfine graphite. Am. Found. Soc. 2012, 120, 347-353.

20. Hernando, J.C.; Diószegi, A. On the primary solidification of compacted graphite iron: Microstructure evolution during isothermal coarsening. Mater. Sci. For. 2018, 925, 90-97. [CrossRef]

21. ASM. Cast Iron Science and Technology; Doru, M.S., Ed.; ASM: Almere, The Netherlands, 2017.

22. Roviglione, A.N. An useful technique for studying graphite in cast iron. Mater. Charact. 1993, 31, 209-216. [CrossRef]

23. Bender, C.L.; Hartmann, P.; Vračar, M.; Adelhelm, P.; Janek, J. On the thermodynamics, the role of the carbon cathode, and the cycle life of the sodium superoxide $\left(\mathrm{NaO}_{2}\right)$ battery. Adv. Energy Mater. 2014, 4, 1301863. [CrossRef]

24. Roviglione, A.N.; Hermida, J.D. X-ray diffraction characterization of flake and compacted graphite in cast iron. Mater. Charact. 1994, 32, 127-137. [CrossRef]

25. Kurz, W.; Fisher, D.J. Fundamentals of Solidification; Trans Tech. Publications: Bäch, Switzerland, 1986; pp. 111-112.

26. Gregorutti, R.W.; Grau, J.E. Mechanical properties of compacted graphite cast iron with different microstructures. Inter. J. Cast Metal. Res. 2014, 27, 275-281. [CrossRef]

27. Placke, T.; Siozios, V.; Schmitz, R.; Lux, S.; Bieker, P.; Colle, C.; Meyer, H.-W.; Passerini, S.; Winter, M. Influence of graphite surface modifications on the ratio of basal plane to "non-basal plane" surface area and on the anode performance in lithium ion batteries. J. Power Sour. 2012, 200, 83-91. [CrossRef] 
28. Olivier, J.P.; Buqa, H.; Kohs, W.; Schröttner, H.; Golob, P.; Winter, M. The Relevance of Graphite Surface Properties for Anode Performance in Lithium Ion Cells-III. Surface Area and Surface Heterogeneieties; Micromeritics Instrument Corp, Inc.: Norcross, GA, USA, 2001.

29. Yuan, J.; Yu, J.-S.; Sundén, B. Review on mechanisms and continuum models of multi-phase transportphenomena in porous structures of non-aqueous Li-Air batteries. J. Power Sour. 2015, 278, 352-369. [CrossRef]

30. Lim, H.-D.; Yun, Y.S.; Ko, Y.; Bae, Y.; Song, M.Y.; Yoon, H.J.; Kang, K.; Jin, H.-J. Three-dimensionally branchedcarbon nanowebs as air-cathode for redox-mediated Li-O2 batteries. Carbon 2017, 118, 114-119. [CrossRef]

31. Ferrari, S.; Quartarone, E.; Tomasi, C.; Bini, M.; Galinetto, P.; Fagnoni, M.; Mustarelli, P. Investigation of ether-based ionic liquid electrolytes for Lithium-O2 batteries. J. Electrochem. Soc. 2015, 162, A3001-A3006. [CrossRef]

32. Laoire, C.O.; Mukerjee, S.; Abraham, K.M.; Plichta, E.J.; Hendrickson, M.A. Influence of nonaqueous solvents on the electrochemistry of oxygen in the rechargeable lithium-air battery. J. Phys. Chem. 2010, 114, 9178-9186. [CrossRef]

33. Guo, L.; Wang, J.; Ma, S.; Zhang, Y.; Wang, E.; Peng, Z. The origin of potential rise during charging of Li-O2 batteries. Sci. China Chem. 2017, 60, 1527-1532. [CrossRef]

34. Lai, J.; Xing, Y.; Chen, N.; Li, L.; Wu, F.; Chen, R. A comprehensive insight into the electrolytes for rechargeablelithium-air batteries. Angew. Chem. 2019, 59, 2974-2997. [CrossRef] [PubMed]

35. Tamakloe, W.; Agyeman, D.A.; Park, M.; Yang, J.; Kang, Y. Polydopamine-induced surface functionalization of carbon nanofiber for Pd deposition enabling an enhanced catalytic activity for oxygen reduction and evolution reactions. J. Mater. Chem. A 2019, 7 , 7396-7405. [CrossRef]

36. Mahne, N.; Schafzahl, B.; Leypold, C.; Leypold, M.; Grumm, S.; Lietgeb, A.; Strohmeier, G.A.; Wilkening, M.; Fontaine, O.; Kramer, D.; et al. Singlet oxygen generation as a major cause for parasitic reactions during cycling of aprotic lithium-oxygen batteries. Nat. Energy 2017, 2, 17036. [CrossRef]

37. Juris, A.; Balzani, V.; Barigelletti, F.; Campagna, S.; Belser, P.; von Zelewsky, A. Ru(II) polypyridine complexes: Photophysics, photochemistry, eletrochemistry, and chemiluminescence. Coordination Chem. Rev. 1988, 84, 85-277. [CrossRef] 